\title{
Compendium of Completed Testing in Support of Rotary Microfiltration at Savannah River Site and Hanford
}

\author{
H. J. Huber \\ Washington River Protection Solutions, LLC \\ Richland, WA 99352 \\ U.S. Department of Energy Contract DE-AC27-08RV14800 \\ EDT/ECN: DRF UC: \\ Cost Center: Charge Code: \\ B\&R Code: Total Pages: 21
}

Key Words: Rotary Microfiltration, Supplemental Treatment

Abstract: This document summarizes the reported development of the rotary microfiltration technology in respect to site specific applications at Savannah River Site and Hanford.

TRADEMARK DISCLAIMER. Reference herein to any specific commercial product, process, or service by trade name trademark, manufacturer, or otherwise, does not necessarily constitute or imply its endorsement, recommendation, or favoring by the United States Government or any agency thereof or its contractors or subcontractors.

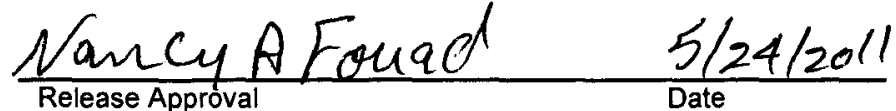

Approved For Public Release

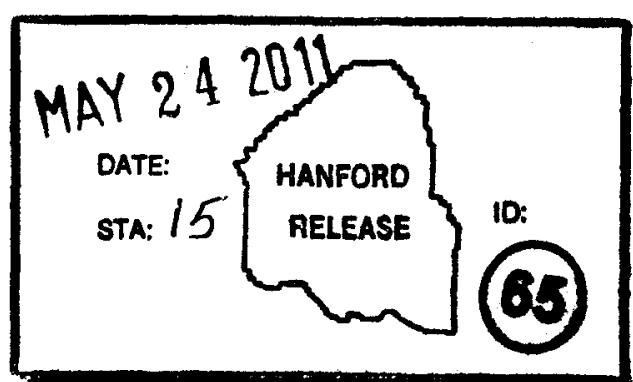

Release Stamp 


\section{Compendium of Completed Testing in Support of Rotary Microfiltration at Savannah River Site and Hanford}

Author

H. J. Huber

Washington River Protection Solutions LLC

Date Published

May 2011

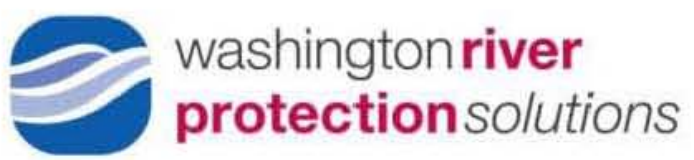

Prepared for the U.S. Department of Energy

Office of River Protection

Contract No. DE-AC27-08RV14800 


\section{Table of Contents}

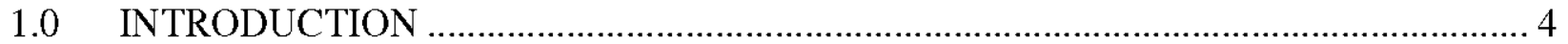

2.0 SUMMARY OF TECHNOLOGY DEVELOPMENT ……............................................ 4

3.0 KEY DOCUMENTATION FOR ROTARY MICROFILTRATION ……....................... 7

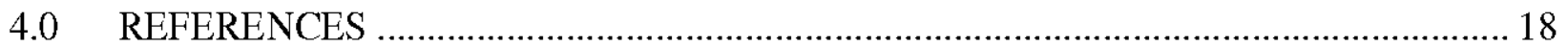

\section{List of Figures}

Figure 1. Overview of Relevant Rotary Microfiltration Investigations..................................... 6 


\section{List of Terms}

$\begin{array}{ll}\text { Abbreviations } \\ \text { CFF } & \text { Cross Flow Filter } \\ \text { CUF } & \text { Cross Flow Ultrafiltration } \\ \text { DOE } & \text { Department of Energy } \\ \text { EM } & \text { Environmental Management } \\ \text { MST } & \text { Monosodium Titanate } \\ \text { RMF } & \text { Rotary Microfilter } \\ \text { SDI } & \text { Silt Density Index } \\ \text { SRNL } & \text { Savannah River National Laboratory } \\ \text { SRS } & \text { Savannah River Site } \\ \text { TMP } & \text { Transmembrane Pressure } \\ \text { TRL } & \text { Technology Readiness Level } \\ \text { WTP } & \text { Waste Treatment and Immobilization } \\ & \\ \text { Units } & \\ \text { gpm/ft } & \\ \text { g/L } & \text { Gallons per minute per square feet } \\ \text { gal } & \text { Gram per Liter } \\ \text { kgal } & \text { Gallon } \\ \text { M } & \text { Kilogallons } \\ \mu & \text { Molar } \\ \text { ntu } & \text { Micrometer } \\ \text { psi } & \text { Nephelometric turbidity units } \\ \text { rpm } & \text { Pounds per square inch } \\ \text { wt\% } & \text { Rotations per minute } \\ & \text { Weight percent } \\ & \end{array}$




\subsection{INTRODUCTION}

This report presents a chronological summary of previous technology development efforts concerning the rotary microfiltration (RMF) unit from SpinTek ${ }^{\mathrm{TM}}$. Rotary microfiltration has been developed for high radiation application over the last decades as one of the optional filtration techniques for supplemental treatment. Supplemental treatment includes a near- or intank solids separation and subsequent cesium removal unit, followed by an immobilization technique; this includes options such as steam reforming, bulk vitrification or cast stone (grout). The main difference between RMF and standard cross flow filtration (CFF) is the disconnection of filtrate flux from feed velocity; i.e., filtrate flux is only dependent on transmembrane pressure, filter fouling and temperature. These efforts have been supported by the U.S. Department of Energy (DOE), Office of Cleanup Technologies since the 1990s by their Environmental Management Program (currently EM-31).

In order to appropriately address future testing needs, a compilation of the relevant previous testing reports was essential. This compendium does not intend to cover all of the presentations/reports that were produced over the last decades but focuses on those of relevance for developing an RMF unit fit for deployment at the Hanford site. The report is split into three parts: (1) an introductory overview, (2) Figure 1 graphically covering the main development steps and its key players and (3) a more detailed table of the citations and brief descriptions of results and recommendations.

\subsection{SUMMARY OF TECHNOLOGY DEVELOPMENT}

The first citation of RMF for treating waste at DOE sites dates back to the early 1990s; the first down select by the Savannah River National Laboratory (SRNL) of available filtration technologies resulted in two candidates chosen for further evaluation - centrifugal (SpinTek) and tubular cross flow filtration systems. Initial tests funded by DOEs Environmental Management Program were performed at West Virginia University, at the Energy and Environmental Research Center (University of North Dakota) and at SRNL. The off-the-shelf setup was not compatible with applications in a radiation area, with many parts deteriorating when exposed to high activity levels thus potentially causing leakage. First applications of the RMF on low-level radioactive waste were evaluated at the Los Alamos National Laboratory but lack of funding discontinued any testing after the first set of scoping tests.

Savannah River National Laboratory continuously improved the technology for the next decade in conjunction with the vendor (SpinTek ${ }^{\mathrm{TM}}$ ) and Oak Ridge National Laboratory. The improvements resulted in a radiation resistant and deployable unit. The focus of these activities was set to (a) evaluate alternative rotary microfilter vendors; (b) redesign the unit for radioactive applications in a highly caustic environment; (c) risk evaluations, downstream impacts and cost and benefits assessments for deployment; (d) performing actual waste bench scale tests and pilotto full scale surrogate testing. 
SpinTek ${ }^{\mathrm{TM}}$ turned out to be the sole provider of a useable unit ${ }^{1}$; their off-the-shelf single disk unit was redesigned to withstand the challenges of a tank farm deployment.

The use of stainless steel for the whole unit, including the filter disks, was one of the major changes from the original design. Other design enhancements for a tank farm compatible unit included eliminating one of the mechanical seals, reducing the general number of parts, decoupling the motor drive from the filter disks and replacing the elastomer seal with an air seal. The first set of disks was epoxy-glued with a Ryton ${ }^{\circledR}{ }^{2}$ center plate and various filter media on the surface. Ryton turned out to be non-functional as center plate substrate material for radioactive applications. The Ryton disk was replaced by an all-steel welded disk with a Pall sintered stainless steel media on either surface and wire mesh as separators. The so-called second generation disks contain a thicker and sturdier wire mesh and are preparedusing laser cutting which results in a significantly higher and more reproducible filtrate flux.

Simulant and actual waste slurry testing was performed by SRNL or by SpinTek using benchscale (single disk), pilot-scale (3-disk) or full-scale (25-disk) units with various SRS related simulants, most of them containing very fine grained monosodium titanate (MST) ${ }^{3}$. Test variables included temperature, transmembrane pressure, feed pressure and nominal pore size of the filter media. The filtrate flux turned out to be significantly above the required $0.01 \mathrm{gpm} / \mathrm{ft}^{2}$ while producing a filtrate clarity of $<4 \mathrm{ntu}$.

For the 1000-hour endurance test in 2010 a simulated SRS-waste with a specifically small particle size distribution was used. One of the main goals was to reduce the intensity of vibrations, thus increasing the life span of the system. The test unit was a $2^{\text {nd }}$ generation 25 -disk RMF with some major improvements over the first generation setup. These improvements included (but were not limited to) improved cooling of the internal journal bearing and use of a non-contact air-seal. The Savannah River Site (SRS) decided in fall 2010 to purchase and install two individual systems of two units each.

For Hanford applications of the RMF system, only two studies have been performed to date. One used the AN-105 simulant in a full scale unit at SRNL and one covered single disk tests on the AN-105 simulant, AN-105 actual waste slurry and an S/SX-farm composite (actual and simulant). A recent technology readiness assessment (RPP-RPT-48092, Rev. 0) of RMF for Hanford applications has identified a technology readiness level (TRL) of $4^{4}$, primarily due to the lack of design application concepts and functional requirements as well as testing of a representative range of Hanford specific simulants and actual wastes.

The most current technological development is the prototypic production of a fully sintered disk with the same Pall filtration media on the surface. This would allow for a much higher filtrate flux and for backflow operation with the implication of the potential for a non-acidic cleaning protocol. Testing planned to be initiated in FY11 will show whether or not this type of disk performs accordingly.

\footnotetext{
${ }^{1}$ In prior reports, Pall, Canzler and Aspect USA are mentioned. However, neither of these companies currently sells an equivalent unit on the US market.

${ }^{2}$ Ryton® is a polyphenyline sulfide material manufactured by Chevron Phillips Chemical Company.

${ }^{3} \mathrm{MST}$ is a material added to SRS salt waste to remove strontium. It is not planned for use at Hanford.

4 TRL 4 refers to completed "component and/or system validation in laboratory environment".
} 
Figure 1. Overview of Relevant Rotary Microfiltration Investigations.

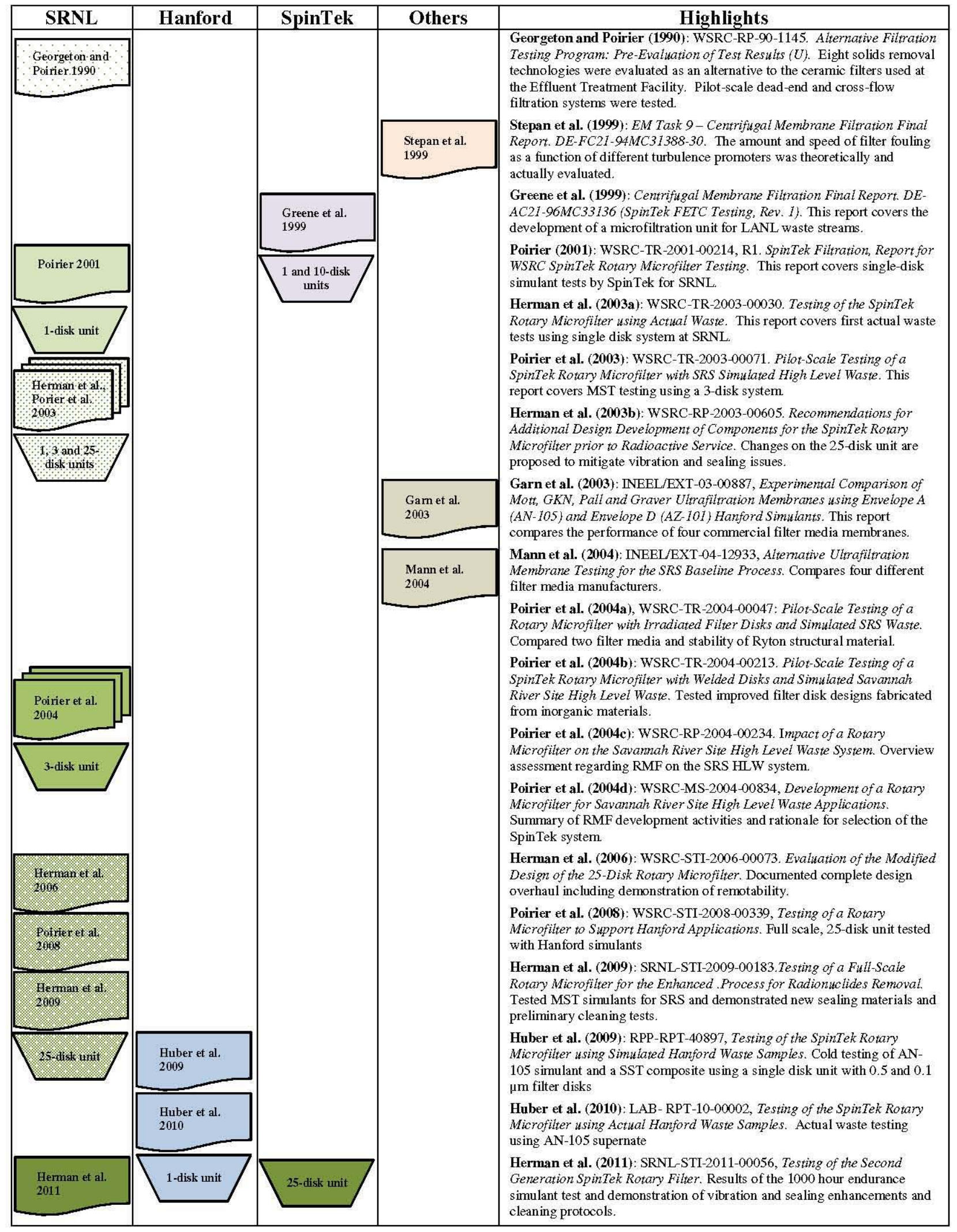




\subsection{KEY DOCUMENTATION FOR ROTARY MICROFILTRATION}

\begin{tabular}{|c|c|}
\hline $\begin{array}{l}\text { Alternative } \\
\text { Filtration Testing } \\
\text { Program: Pre- } \\
\text { Evaluation of Test } \\
\text { Results }(U) .\end{array}$ & $\begin{array}{l}\text { Eight solids removal technologies were evaluated as an alternative to the } \\
\text { ceramic filters used at the Effluent Treatment Facility. These included a } \\
\text { centrifugal and tubular ultrafilter, deep bed filter, backwashable cartridge } \\
\text { filter, porous metal filter, stainless steel mesh filter, tubular fabric filter, } \\
\text { centrifuge and electrocoagulator. Pilot-scale units of dead-end and cross- } \\
\text { flow filtration systems were tested on a standard wastewater simulant. } \\
\text { Turbidity requirements were <1 ntu and silt density index (SDI)<3. The } \\
\text { evaluation considered simplicity of operation, anticipated fouling, } \\
\text { cleaning and minimal waste production. } \\
\text { Summary of Results: } \\
\text { - The centrifugal ultrafilter (SpinTek) and the tubular ultrafilter were } \\
\text { determined to be the most efficient. } \\
\text { - Deep bed filtration was also found to be capable of producing the } \\
\text { desired filtrate quality, but it has drawbacks relating to utility. } \\
\text { The results from testing the back-washable cartridge filter were } \\
\text { inconclusive. } \\
\text { The stainless steel mesh, porous metal and tubular fabric filters, } \\
\text { centrifuge, and electro-coagulation pretreatment were shown to be } \\
\text { inefficient as alternatives. } \\
\text { Recommendations: } \\
\text { - The centrifugal ultrafilter and the tubular ultrafilter should be } \\
\text { - A deep bed filter should currently be considered as a third alternative, } \\
\text { in case membrane technologies are later found to be ineffective. } \\
\text { credibility of the backwashable cartridge filter as a third alternative. }\end{array}$ \\
\hline $\begin{array}{l}\text { EM Task } 9- \\
\text { Centrifugal } \\
\text { Membrane } \\
\text { Filtration Final } \\
\text { Report }(\text { DE-FC21- } \\
\text { 94MC31388-30). }\end{array}$ & $\begin{array}{l}\text { This study was focused on the theoretical and actual evaluation of } \\
\text { different turbulence promoter shapes on the amount and speed of filter } \\
\text { fouling. Angle-bladed promoters were described as potentially reducing } \\
\text { gel layer formation. The report summarizes the theoretical aspects on } \\
\text { fluid flow in rotating systems. The test matrix incorporated three different } \\
\text { promoter shapes (regular, angle-bladed forward, angle bladed backward), } \\
\text { two spinning speeds ( } 900 \text { and } 1200 \mathrm{rpm} \text { ) and two feed pressures ( } \sim 40 \text { and } \\
\sim 60 \text { psi); data recorded were filtrate flux and power consumption as } \\
\text { indicators for cake buildup. } \\
\text { Summary of Results: } \\
\text { - The original design with straight edges showed the best results, i.e., } \\
\text { highest flux with lowest power consumption. Both versions of angle- } \\
\text { bladed promoters had worse performance. } \\
\text { - Beveled-Edge Promoters showed improved performance, however, }\end{array}$ \\
\hline
\end{tabular}




\begin{tabular}{|c|c|}
\hline & $\begin{array}{l}\text { these results are inconclusive since the slurry had a lower solids content } \\
\text { ( } 20 \mathrm{wt} \% \text { as opposed to } 27 \mathrm{wt} \% \text { in non beveled-edge test) } \\
\text { - No conclusions were drawn. }\end{array}$ \\
\hline $\begin{array}{l}\text { Centrifugal } \\
\text { Membrane } \\
\text { Filtration Final } \\
\text { Report (DE-AC21- } \\
96 M C 33136(F E T C \\
\text { Testing, Rev. 1). }\end{array}$ & $\begin{array}{l}\text { This report covers the development of a microfiltration unit for LANL } \\
\text { waste streams. The project was 2-phased, with this report covering the } \\
\text { first phase, a scale-up of the single-disk unit (ST-II-1) to a 10-disk } \\
\text { prototype unit (ST-II-10). } \\
\text { Summary of Results: } \\
\text { - Short term tests ( } 2 \text { hours) using three different types of concentrated } \\
\text { slurries (styrene-butadiene [SBD] latex, kaolin clay and Al(OH) } 3 \text { ) } \\
\text { confirmed that the specific productivity (in gallons of permeate } \\
\text { produced per minute per unit membrane surface area per psi of pressure } \\
\text { gradient through the membrane [gpm/ft }{ }^{2} \text { psi]), filtrate flux decline and } \\
\text { membrane rejection characteristics were maintained. } \\
\text { - Titanium-oxide particles in the range of } 1-5 \text { m mere used for short } \\
\text { term parametric tests on slurries of varying composition to identify the } \\
\text { influence of transmembrane pressure (TMP), rotation speed, solids } \\
\text { concentration, temperature and organic impurities; an optimum rotor } \\
\text { rpm ( } 1200 \text { rpm) was identified, and the other parameters followed the } \\
\text { theoretical expectations (higher T and/or higher TMP = higher flux). } \\
\text { - A } 24 / 7 \text { test was performed with the single and the ten disk unit using a } \\
\text { concentrate Ti-oxide slurry at one set of process conditions. Over the } \\
168 \text { hours of testing, the flux decline varied between } 10 \text { and } 20 \text { percent } \\
\text { resulting in } 300 \text { gal/ft }{ }^{2} \text { psi for the single disk unit and resulting in } 500 \\
\text { gal/ft }{ }^{2} \text { psi for the } 10 \text {-disk unit. Solids concentrations ranged between } 38 \\
\text { and } 48 \text { wt.\%. } \\
\text { Key Issues and Recommendations: } \\
\text { - The second phase of the project was aiming at the operation of a full- } \\
\text { scale two-stage unit at LANL (no further funding was available). }\end{array}$ \\
\hline $\begin{array}{l}\text { SpinTek Filtration, } \\
\text { Report for WSRC } \\
\text { SpinTek Rotary } \\
\text { Microfilter Testing. }\end{array}$ & $\begin{array}{l}\text { SpinTek performed simulant tests for the Savannah River Site on a single- } \\
\text { disk ST-II- } 1 \text { unit. "Average" simulated SRS high level waste was } \\
\text { produced using a brine solution (without Al-nitrate and Cs-nitrate) and } \\
\text { adding a mixture of sludge and monosodium titanate (MST) to insoluble } \\
\text { solids loading between } 0.6 \mathrm{~g} / \mathrm{L} \text { and } 60 \mathrm{~g} / \mathrm{L} \text {. Tests were performed at } 40 \\
\text { psi TMP and } 1170 \mathrm{rpm} \text { rotor speed; temperatures ranged between } 66 \text { and } \\
102 \mathrm{~F} \text {. As filter media, a } 0.5 \mu \mathrm{m} \text { stainless steel filter and a } 0.1 \mu \mathrm{m} \\
\text { ceramic filter were used. } \\
\text { Summary of Results: } \\
\text { - The stainless steel and the ceramic membrane resulted in } \\
\text { approximately the same filtrate flux; the disk center was made of } \\
\text { Ryton. } \\
\text { - However, the test run using a } 0.5 \mu \mathrm{m} \text { ceramic filter instead of the } 0.1\end{array}$ \\
\hline
\end{tabular}




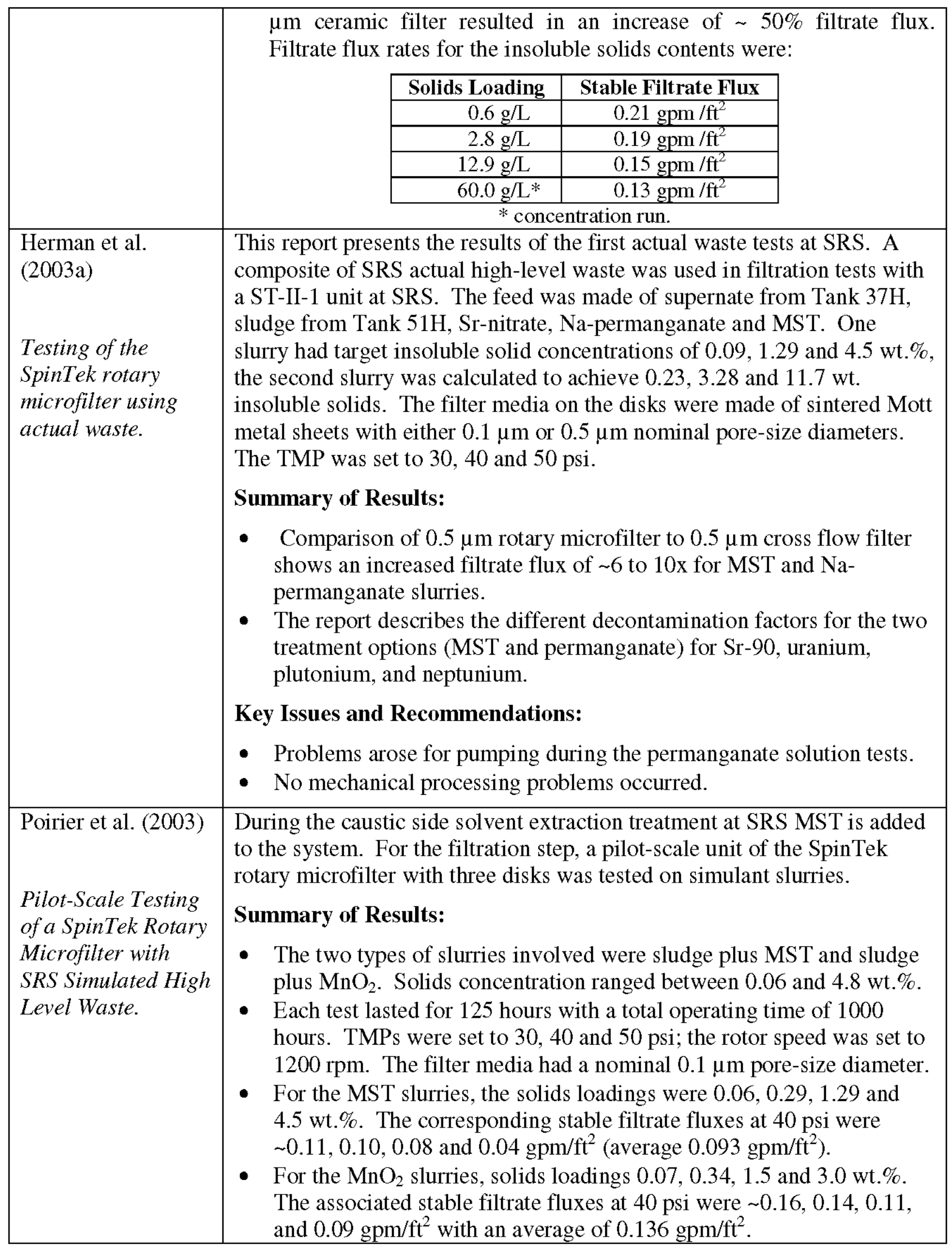




\begin{tabular}{|c|c|}
\hline & $\begin{array}{l}\text { - In terms of permeance (i.e., filtrate flux per psi TMP), the rotary } \\
\text { microfilter showed a } 1.5-2.8 x \text { increase in filter flux compared to a } \\
\text { Mott crossflow filter for the MST slurry, but a } 30 \% \text { decrease for the } \\
\mathrm{MnO}_{2} \text { slurries. } \\
\text { Key Issues and Recommendations: } \\
\text { - During the tests with MST and sludge no operational errors occurred. } \\
\text { - To simulate an unplanned shutdown a "rotor stop test" was } \\
\text { performed, that caused a complete system failure. Disassembling the } \\
\text { unit was the only path of recovery; the slurry had packed to } 40 \text { wt.\% } \\
\text { solids loading. }\end{array}$ \\
\hline $\begin{array}{l}\text { Recommendations } \\
\text { for additional } \\
\text { design development } \\
\text { of components for } \\
\text { the SpinTek Rotary } \\
\text { Microfilter prior to } \\
\text { radioactive service. }\end{array}$ & $\begin{array}{l}\text { Modifications for the 25-disk unit are presented based on single and 3- } \\
\text { disk unit experience. To accommodate the design changes extensive } \\
\text { redesign of the filter chamber seemed necessary. However, the } \\
\text { implementation into the current design of most of the changes would } \\
\text { cause minimal impact on costs of the units. } \\
\text { Summary of Recommendations: } \\
\text { - Areas of improvement were identified as: manufacturing tolerances } \\
\text { (especially for O-ring grooves), mechanical seals, and electronics and } \\
\text { instrumentation. } \\
\text { To extend the service life of the filter unit, and to make maintenance } \\
\text { more remote friendly the following re-engineering from the standard } \\
\text { unit were recommended: eliminating one of the mechanical seals, } \\
\text { reducing the number of elastomer seals, reducing the number of parts, } \\
\text { deployment of an all steel filter disk, and decoupling the motor drive } \\
\text { from the filter disks. }\end{array}$ \\
\hline $\begin{array}{l}\text { Experimental } \\
\text { Comparison of } \\
\text { Mott, GKN, Pall } \\
\text { and Graver } \\
\text { Ultrafiltration } \\
\text { Membranes using } \\
\text { Envelope A (AN- } \\
\text { 105) and Envelope } \\
D(\text { AZ-101) } \\
\text { Hanford Simulants. }\end{array}$ & $\begin{array}{l}\text { This paper does not cover any rotary microfiltration testing; however, it } \\
\text { contains the comparison between the different stainless steel membrane } \\
\text { media that were on the market at that time. } \\
\text { Summary of Results: } \\
\text { - The membranes were tested as a single tube filter (cross flow } \\
\text { ultrafiltration, CUF) module for the Hanford Waste Treatment Plant } \\
\text { (WTP). All units were } 24 \text { inches in length, but the Mott and GKN are } \\
\text { 1/2 inch inside diameter whereas the Pall and Graver are } 3 / 8 \text { inch inside } \\
\text { diameter. Pore size ratings are either absolute or nominal } 0.1 \mu \text { m. } \\
\text { Each of the four membranes was tested using two different solids } \\
\text { loadings for both Hanford simulants (Env. A had 0.6 and } 20 \text { wt.\%; } \\
\text { Env. D had } 5 \text { and } 10 \text { wt.\%). } \\
\text { The Mott membrane was procured from the Mott Metallurgical } \\
\text { Corporation (USA), the membrane manufactured and obtained from } \\
\text { GKN (Germany) was a SIKA-R sintered stainless steel membrane on a } \\
\text { sintered stainless steel substrate. The membrane procured from the } \\
\text { Pall Corporation (USA) was also a MEMBRALOX zirconium oxide }\end{array}$ \\
\hline
\end{tabular}




\begin{tabular}{|c|c|}
\hline & $\begin{array}{l}\text { ceramic coating on a sintered stainless steel substrate and the } \\
\text { membrane procured from Graver Technologies (USA) was a } \\
\text { SCEPTER design, sintered titanium oxide coating on a } 316 \mathrm{~L} \text { stainless } \\
\text { steel substrate. } \\
\text { - The Mott achieved higher final flux than the GKN at each test } \\
\text { condition using Envelope A } 20 \mathrm{wt} \% \text { slurry. } \\
\text { The Pall achieved higher final flux than the Graver at each test } \\
\text { condition using Envelope A } 20 \mathrm{wt} \% \text { slurry. }\end{array}$ \\
\hline $\begin{array}{l}\text { Alternative } \\
\text { Ultrafiltration } \\
\text { Membrane Testing } \\
\text { for the SRS baseline } \\
\text { Process. }\end{array}$ & $\begin{array}{l}\text { Four manufactures of stainless steel filter media were comparatively tested } \\
\text { with a SRS supernate simulant in a CUF setup; no rotary microfiltration } \\
\text { testing was performed. Filter media from Mott }(0.1 \text { and } 0.5 \mu \mathrm{m}) \text {, Graver } \\
(0.07 \mu \mathrm{m}) \text {, Pall }(0.1 \mu \mathrm{m} \text { and } 0.8 \mu \mathrm{m}) \text { and GKN }(0.1 \mu \mathrm{m}) \text { were evaluated. } \\
\text { A two-phase set of tests evaluated the filtrate flux consistency and clarity } \\
\text { with a water-based } 5 \mathrm{wt} \% \mathrm{SrCO}_{3} \text { slurry and a SRS average salt supernate } \\
\text { simulant at solids loadings of } 0.06,0.29 \text { and } 4.5 \mathrm{wt} \% \text {. } \\
\text { Summary of Results: } \\
\text { - Membranes with a ceramic asymmetric coating (Graver, Pall) had } \\
\text { typically the highest average steady state fluxes for all solid loadings } \\
\text { evaluated. } \\
\text { It is postulated that small particles present in solution were unable to } \\
\text { penetrate the ceramic layer, thus producing surface filtration where the } \\
\text { filter cake acts as the filter medium. Conversely, membranes without } \\
\text { the asymmetric ceramic coating were susceptible to the small particles } \\
\text { present in solution penetrating into the internal pore structure of the } \\
\text { membrane, thus producing depth filtration where the porosity is greatly } \\
\text { reduced by particles trapped within the interstices of the internal } \\
\text { structure. }\end{array}$ \\
\hline $\begin{array}{l}\text { Pilot-Scale Testing } \\
\text { of a Rotary } \\
\text { Microfilter with } \\
\text { Irradiated Filter } \\
\text { Disks and } \\
\text { Simulated SRS } \\
\text { Waste. }\end{array}$ & $\begin{array}{l}\text { Three types of filter disks were tested in the pilot-scale } 3 \text {-disk unit. The } \\
\text { disks contained filter media made of stainless steel }(0.1 \mu \mathrm{m} \text { and } 0.5 \mu \mathrm{m}) \\
\text { and of ceramic/stainless steel }(0.1 \mu \mathrm{m}) \text {. The structural material however } \\
\text { was Ryton, which was tested on irradiation destabilization by exposing it } \\
\text { to a radiation dose estimated over a period of } 2.5-5 \text { years }(83-165 \\
\text { MRad). The hardness of the Ryton was measured before and after the } \\
\text { irradiation of the disks; test runs with the irradiated disks provided filtrate } \\
\text { flux and clarity data. Slurries involved in the tests contained } 0.29 \text { and } 4.5 \\
\text { wt.\% solids of MST and sludge in supernate. The supernate was decanted } \\
\text { from previous tests and readjusted to } 0.29 \text { wt } \% \text { solids. After the first tests } \\
\text { solids were added to the higher loading. } \\
\text { Summary of Results: } \\
\text { - None of the nine ( } 3 \times 3) \text { disks tested experienced a catastrophic failure } \\
\text { from radiation exposure, but some evidence of delamination between } \\
\text { the epoxy and the base Ryton existed. } \\
\text { The flux with the irradiated filter disks was } 35 \text { - } 40 \% \text { lower than the }\end{array}$ \\
\hline
\end{tabular}




\begin{tabular}{|c|c|}
\hline & $\begin{array}{l}\text { flux measured with unirradiated filter disks. Possible explanations are } \\
\text { differences in the feed (smaller particle size for the irradiated filter } \\
\text { tests) or lack of appropriate cleaning after the } 2002 \text { tests. } \\
\text { In detail, the } 0.1 \mu \mathrm{m} \text { ceramic/stainless steel filter produced the highest } \\
\text { flux. The } 0.1 \mu \mathrm{m} \text { stainless steel filter produced higher flux than the } 0.5 \\
\mu \mathrm{m} \text { stainless steel filter at the lower solids loading, and the same flux } \\
\text { at the higher solids loading. } \\
\text { Key Issues: } \\
\text { - Scanning electron microscope pictures show particles filling the pores } \\
\text { of the } 0.5 \mu \mathrm{m} \text { filter, and solid particles on the surface of the } 0.1 \mu \mathrm{m} \\
\text { filter. }\end{array}$ \\
\hline $\begin{array}{l}\text { Pilot-Scale Testing } \\
\text { of a SpinTek Rotary } \\
\text { Microfilter with } \\
\text { Welded Disks and } \\
\text { Simulated } \\
\text { Savannah River Site } \\
\text { High Level Waste }\end{array}$ & $\begin{array}{l}\text { Tests were performed on the pilot-scale unit with newly developed disks. } \\
\text { The standard filter disk for the SpinTek rotary microfilter was constructed } \\
\text { using a Ryton® center support plate, polypropylene mesh and sheet of } \\
\text { filter media all joined by an epoxy bead around the outer edge. Testing of } \\
\text { this disk configuration demonstrated that the polymers and epoxy joining } \\
\text { would not stand up in combined caustic and radioactive service for more } \\
\text { than a few years operation. } \\
\text { The original design was modified to construct the filter disk using all } \\
\text { metal parts that are attached and sealed using welding technology. Filter } \\
\text { disks were fabricated using three different vendor membranes, two 0.1 } \mu \text { m } \\
\text { stainless steel membranes (Mott and Pall Corp.) and a third membrane } \\
\text { (TruMem), with a thin ceramic coating on a thicker stainless steel } \\
\text { substrate (for specs on each disk see introduction in Poirier et al. (2005). } \\
\text { The redesign work eliminated polymers from the disks, but did not } \\
\text { eliminate polymers from the filter unit; the remaining polymers are in the } \\
\text { O-ring seals. The elastomer selected (EPDM), when in compression, } \\
\text { maintains its integrity in radiation fields and should be suitable for } \\
\text { service. } \\
\text { Summary of Results: } \\
\text { - Filter flux with the welded disks was significantly less than the flux in } \\
\text { comparable tests with filter disks fabricated using epoxy. The } \\
\text { differences are apparently due to changes in the spacing between the } \\
\text { filter disks and the turbulence promoters and changes in the } \\
\text { turbulence promoter thickness added for the tests. } \\
\text { The Pall filter media produced higher flux than the Mott filter media. }\end{array}$ \\
\hline $\begin{array}{l}\text { Impact of a Rotary } \\
\text { Microfilter on the }\end{array}$ & $\begin{array}{l}\text { This report documents the assessment on the impact of the rotary } \\
\text { microfilter on the Savannah River Site High Level Waste system. } \\
\text { Summary of Results: } \\
\text { Positive impacts to SRS High Level Waste System (compared to CFF): }\end{array}$ \\
\hline
\end{tabular}




\begin{tabular}{|c|c|}
\hline $\begin{array}{l}\text { Savannah River Site } \\
\text { High Level Waste } \\
\text { System. }\end{array}$ & $\begin{array}{l}\text { - No new chemicals added to the actinide removal process. } \\
\text { - Less frequent chemical cleaning and less oxalic acid (estimated } 97 \% \text {, } \\
\text { or } 16,000 \text { gal per year, reduction in cleaning chemicals). } \\
\text { - Higher filtrate throughput, allowing a treatment of the SRS High } \\
\text { Level Waste needing actinide removal. Two } 25 \text { disk rotary filter ( } 50 \\
\mathrm{ft}^{2} \text { filter area total) would produce the same throughput as a } 230 \mathrm{ft}^{2} \\
0.1 \mu \mathrm{m} \text { cross-flow filter. } \\
\text { - The ARP could concentrate the waste slurries to } 12 \mathrm{wt} \% \text { rather than } 5 \\
\text { wt\%, with no adverse impact on filter flux (= reduction of annual } \\
\text { recycle generation by } 14 \text { kgal). } \\
\text { Negative impacts of the rotary microfilter to the SRS High Level Waste } \\
\text { System: } \\
\text { Because of the rotating parts, the system may require more frequent } \\
\text { maintenance and replacement than the baseline cross-flow filters. }\end{array}$ \\
\hline $\begin{array}{l}\text { Poirier et al. } \\
\text { (2004d) } \\
\text { Development of a } \\
\text { Rotary Microfilter } \\
\text { for Savannah River } \\
\text { Site High Level } \\
\text { Waste Applications. }\end{array}$ & $\begin{array}{l}\text { A summary of the development efforts during 2003-2004 is provided in a } \\
\text { presentation paper for the waste management (WM) symposium. This } \\
\text { report specifically contains an alternative manufacturer description for } \\
\text { rotary microfilter systems and the rationale for choosing SpinTek over } \\
\text { ASPECT USA, Canzler LLC and Pall Corporation. }\end{array}$ \\
\hline $\begin{array}{l}\text { Rotary Microfilter } \\
\text { Media Evaluation. }\end{array}$ & $\begin{array}{l}\text { Four filter media were compared in two suites of tests. All media were } \\
\text { evaluated with a stirred-cell dead end filter setup. The filter media } \\
\text { included: } \\
\text { - } \quad \text { Pall PMM: } 150 \mu \mathrm{m} \text { thick sintered stainless steel powder matrix within } \\
\text { stainless steel wire mesh. Nominal pore sizes of } 0.1,0.5,1.0,1.5,2.0 \\
\mu \mathrm{m} \text { used. Pall PMM M050 } 0.5 \mu \mathrm{m} \text { nominal. } \\
\text { - Pall PSS: } 1143 \mu \mathrm{m} \text { thick sintered stainless steel powder matrix. } \\
\quad \text { Nominal pore sizes of } 0.5,0.9 \mu \mathrm{m} \text { and F and H grade. } \\
\text { - TruMem by Aspect: stainless steel substrate ( } 185 \mu \mathrm{m}) \text { with } 15 \mu \mathrm{m} \text { It- } \\
\text { oxide coating. } \\
\text { - Mott: } 711 \mu \mathrm{m} \text { tick sintered stainless steel powder matrix. } \\
\text { Results showed that Pall PMM outperforms the Pall PSS and Mott and } \\
\text { larger pore sizes show higher flux. PMM 0.1 and } 0.5 \text { showed } \\
\text { significantly better turbidity than larger pore sizes; TruMem had best } \\
\text { results. Ease of use during disk fabrication is another point for PMM. } \\
\text { Three welded disk types were compared in } 3 \text {-disk unit }(0.1 \mu \mathrm{m} \text { TruMem, } \\
0.1 \mu \mathrm{m}, 0.5 \mu \mathrm{m} \text {, and } 1.0 \mu \mathrm{m} \text { Pall PMM) using slurries with } 0.05 \text { to } 12.5 \\
\text { wt\% solids. } \\
\text { Summary of Results: }\end{array}$ \\
\hline
\end{tabular}




\begin{tabular}{|c|c|}
\hline & $\begin{array}{l}\text { - The } 0.1 \mu \mathrm{m} \text { nominal TruMem ceramic and the Pall PMM M050 } \\
\text { stainless steel filter media produced the highest flux in rotary filter } \\
\text { testing. } \\
\text { - The Pall PMM M050 media produced the highest flux of the stainless } \\
\text { steel media tested in rotary filter testing and met filtrate quality } \\
\text { requirements. } \\
\text { - The } 0.1 \mu \mathrm{m} \text { TruMem and Pall PMM M010 media met filtrate quality } \\
\text { requirements as well. } \\
\text { - The Pall PMM M050 media proved more durable and easier to weld } \\
\text { than the } 0.1 \mu \mathrm{m} \text { TruMem® media. } \\
\text { Recommendations: } \\
\text { Pall PMM M050 filter media was recommended for the } 2^{\text {nd }} \text { generation } \\
\text { rotary microfilter. This media produced the highest flux of the stainless } \\
\text { steel media tested while meeting the turbidity criteria with a better } \\
\text { durability than the TruMem media. }\end{array}$ \\
\hline $\begin{array}{l}\text { Testing and } \\
\text { Evaluation of the } \\
\text { Modified Design of } \\
\text { the } 25 \text { Disk Rotary } \\
\text { Microfilter. }\end{array}$ & $\begin{array}{l}\text { A complete design overhaul of the commercial } 25 \text {-disk unit was done by } \\
\text { SRNL personnel. The report provides the results of tests to: } \\
\text { - } \quad \text { Demonstrate remote assembly and removal of the disk stack using an } \\
\text { overhead crane. } \\
\text { Evaluate the ability of flush water to remove soluble (e.g., Cesium- } \\
\text { 137) and insoluble (i.e., sludge) solids from the filter unit prior to } \\
\text { removal and maintenance. } \\
\text { - Evaluate the ability of the full-scale unit to filter a simulant of SCIX } \\
\text { feed and to continuous wash a simulated SRS sludge. } \\
\text { Summary of Results: } \\
\text { - The re-designed rotary filter performed well in all aspects of testing. } \\
\text { Filter performance testing used slurries containing } 0.06 \text { to } 15 \text { wt\% } \\
\text { insoluble solids in a } 3.2 \mathrm{M} \text { sodium simulated supernate. The filter } \\
\text { produced filtration rates between } 3 \text { and } 7 \text { gpm for the } 25 \text {-disk filter } \\
\text { with a turbidity of <3 ntu. } \\
\text { About } 80 \text { gal of sludge ( } 3.2 \mathrm{M} \text { Na supernate) were washed using } 207 \\
\text { gal inhibited water to } 0.3 \mathrm{M} \text {. The washed } 15 \text { wt } \% \text { insoluble solids } \\
\text { were concentrated to } 20 \text { wt\% without operational problems at a } \\
\text { filtrate rate of } 4.2 \text { gpm (calc. for } 35^{\circ} \mathrm{C} \text { ). } \\
\text { Recommendations for design improvements: } \\
\text { - The design of the support arm for the SCIX plug/filter module } \\
\text { requires a modification to allow additional spacing for the motor plate } \\
\text { mounting bolts. The addition of a lifting point is required to } \\
\text { efficiently move the motor for access to the filter stack since lifting } \\
\text { points are not provided on the procured motors. } \\
\text { impregnated silicon-carbide is expected to double the life of the seal. }\end{array}$ \\
\hline
\end{tabular}




\begin{tabular}{|c|c|}
\hline & $\begin{array}{l}\text { Replacement of the current seal with an air seal could increase the } \\
\text { lifetime to } 5 \text { years. } \\
\text { The bottom bushing showed wear due to a misalignment during the } \\
\text { manufacture of the filter tank. Replacing the graphite bushing with a } \\
\text { more wear resistant material such as a carbide material will increase } \\
\text { the lifetime of the bushing. }\end{array}$ \\
\hline $\begin{array}{l}\text { Poirier et al. (2008) } \\
\text { Testing of a Rotary } \\
\text { Microfilter to } \\
\text { Support Hanford } \\
\text { Applications. }\end{array}$ & $\begin{array}{l}\text { A full-scale } 25 \text {-disk unit with } 0.5 \mu \mathrm{m} \text { Pall PMM media stainless steel } \\
\text { welded disks was evaluated on a Hanford } \mathrm{AN}-105 \text { simulant with } 0.06 \text {, } \\
0.29 \text { and } 1.29 \mathrm{wt} \% \text { solids loadings. } \\
\text { Summary of Results: } \\
\text { - The filter flux for the individual solids loadings was on average: } \\
\quad 0.06 \mathrm{wt} \% \rightarrow 0.26 \mathrm{gpm} / \mathrm{ft}^{2}(6.25 \mathrm{gpm} \text { total) } \\
\quad 0.29 \mathrm{wt} \% \rightarrow 0.17 \mathrm{gpm} / \mathrm{ft}^{2}(4 \mathrm{gpm} \text { total) } \\
\quad 1.29 \mathrm{wt} \% \rightarrow 0.10 \mathrm{gpm} / \mathrm{ft}^{2} \text { ( } 2.4 \mathrm{gpm} \text { total). } \\
\text { - The data show the rotary filter produces a higher flux than the cross- } \\
\text { flow filter, but the improvement is not as large as seen in previous } \\
\text { testing. } \\
\text { - Filtrate turbidity measured }<4 \text { NTU in all samples collected. } \\
\text { Inspection of the seal faces after } \sim 140 \text { hours of operation showed an } \\
\text { expected amount of initial wear, no passing of process fluid through } \\
\text { the seal faces, and very little change in the air channeling grooves on } \\
\text { the stationary face. } \\
\text { Recommendations: } \\
\text { - During production, the filter should be rinsed with filtrate or dilute } \\
\text { caustic and drained prior to an extended shutdown to prevent the } \\
\text { formation of a layer of settled solids on top of the filter disks. } \\
\text { Based on the observed polishing at the bottom of the shaft bushing, } \\
\text { improving the shaft bushing by holding it in place with a locking ring } \\
\text { is recommended as well as incorporated grooves to provide additional } \\
\text { cooling. } \\
\text { Hanford should test other pore size media to determine the optimum } \\
\text { pore size for Hanford waste. }\end{array}$ \\
\hline $\begin{array}{l}\text { Herman et al. } \\
\text { (2009) } \\
\text { Testing of a Full- } \\
\text { Scale Rotary } \\
\text { Microfilter for the } \\
\text { Enhanced Process } \\
\text { for Radionuclides } \\
\text { Removal. }\end{array}$ & $\begin{array}{l}\text { Simulant sludge from SRS Tank } 8 \text { blended with monosodium titanate } \\
\text { (MST) was tested on the full-scale unit with a newly incorporated John } \\
\text { Crane Type } 28 \mathrm{LD} \text { gas-cooled seal. Insoluble solids concentrations were } \\
0.06 \mathrm{wt} \% \text { and } 5 \mathrm{wt} \% \text {. } \\
\text { Summary of Results: } \\
\text { - The filter flux for the individual solids loadings was on average: } \\
\quad 0.06 \mathrm{wt} \% \rightarrow 0.09 \mathrm{gpm} / \mathrm{ft}^{2}(2.2 \mathrm{gpm} \text { total }) \text { at } 40 \mathrm{psi} \mathrm{TMP} \\
5 \mathrm{wt} \% \rightarrow 0.05 \mathrm{gpm} / \mathrm{ft} 2(1.2 \mathrm{gpm} \text { total }) \text { at } 60 \mathrm{psi} \mathrm{TMP}\end{array}$ \\
\hline
\end{tabular}




\begin{tabular}{|c|c|c|c|c|c|}
\hline & \multicolumn{5}{|c|}{$\begin{array}{l}\text { - The filtration rate follows a linear relationship from } 20 \text { to } 60 \text { psi TMP. } \\
\text { - Chemical cleaning was successfully performed with } 50 \text { liters of } 4 \mathrm{M} \\
\text { nitric acid; flux was restored to } 88 \% \text { of the initial flux at } 5 \mathrm{wt} \% \text { solids. } \\
\text { - The main shaft showed no sign of passing of process fluid through the } \\
\text { seal. The rotary joint showed signs of leakage in the upper and lower } \\
\text { seal. Vibration is the primary cause of leakage. } \\
\text { Recommendations: } \\
\text { - Mechanical improvements of seals and rotary joint. } \\
\text { - Incorporate a separate motor stand. } \\
\text { - Reduce the tolerances of the filter disks and disk hub to improve load } \\
\text { balances. }\end{array}$} \\
\hline \multirow[t]{4}{*}{$\begin{array}{l}\text { Huber et al. (2009) } \\
\text { Testing of the } \\
\text { SpinTek Rotary } \\
\text { Microfilter using } \\
\text { Simulated Hanford } \\
\text { Waste Samples. }\end{array}$} & \multicolumn{5}{|c|}{$\begin{array}{l}\text { This report covers cold testing of a single-disk unit at } 222-\mathrm{S} \text { with three } \\
\text { stainless steel disks; two with } 0.5 \mu \mathrm{m} \text { nominal pore size, one with } 0.1 \mu \mathrm{m} \text {. } \\
\text { Feed slurries were an AN-105 simulant and a SST composite simulant. } \\
\text { The AN-105 simulant was previously tested on the full-scale unit at } \\
\text { SRNL (WSRC-STI-2008-00339). } \\
\text { Summary of Results: } \\
\text { - The filtrate flux differences between the two } 0.5 \mu \mathrm{m} \text { disks were } \\
\text { overwhelming the differences between average } 0.5 \mu \mathrm{m} \text { and the } 0.1 \\
\mu \text { m disk flux. } \\
\text { The differences within the } 0.5 \mu \mathrm{m} \text { disks complicate a comparison to } \\
\text { the SRNL 25-disk fluxes: }\end{array}$} \\
\hline & \begin{tabular}{|c|} 
Flux $\left[g p m / \mathrm{ft}^{2}\right]$ \\
corr. to $35^{\circ} \mathrm{C}$
\end{tabular} & $\begin{array}{l}\text { Average of } \\
\text { all } 3 \text { disks }\end{array}$ & $\frac{0.5 p}{\text { Lower flux }}$ & $\frac{\text { disks }}{\text { Higher flux }}$ & \\
\hline & \begin{tabular}{|l|}
$0.29 \mathrm{wt} \%$ \\
\end{tabular} & 0.34 & & & \\
\hline & \multicolumn{5}{|c|}{$\begin{array}{l}\text { A major influence on the flux in the single disk unit is the torque on } \\
\text { the disc hub. } \\
\text { The feed flow was shown to have little to no influence on the filtrate } \\
\text { flux. } \\
\text { Recommendations: } \\
\text { - Improve quality control during disk production. }\end{array}$} \\
\hline $\begin{array}{l}\text { Testing of the } \\
\text { SpinTek Rotary } \\
\text { Microfilter using } \\
\text { actual Hanford } \\
\text { Waste Samples. }\end{array}$ & \multicolumn{5}{|c|}{$\begin{array}{l}\text { Actual waste testing using slurries of } \mathrm{AN}-105 \text { supernate and a S/SX farm } \\
\text { composite (called SST) is reported. Two disks were put into the } 1-\mathrm{F} \mathrm{hot} \\
\text { cell, one with } 0.5 \mu \mathrm{m} \text { nominal diameter, one with } 0.1 \mu \mathrm{m} \text {. The } 0.5 \mu \mathrm{m} \\
\text { disk was the one with the higher flux in the cold testing. } \\
\text { Summary of Results: } \\
\text { - The filtrate fluxes were significantly lower than the equivalent } \\
\text { simulants. The ratios between actual and simulant fluxes were: } 0.16 \mathrm{x} \\
\text { to } 0.24 \mathrm{x} \text { for SST, } 0.16 \mathrm{x} \text { to } 0.20 \mathrm{x} \text { for } \mathrm{AN}-105 \text {. } \\
\text { - Cleaning the disks in the unit with a } 1 \mathrm{M} \text { nitric acid solution caused }\end{array}$} \\
\hline
\end{tabular}




\begin{tabular}{|c|c|}
\hline & $\begin{array}{l}\text { the flux to return to } 50 \% \text { of the original flux in the cold testing. } \\
\text { The } 0.1 \mu \mathrm{m} \text { disk did not show any increased filtration rate over the } 0.5 \\
\mu \mathrm{m} \text { disk }\left(0.07 \mathrm{gpm} / \mathrm{ft}^{2} \text { for } 0.5 \mu \mathrm{m} \text { disk on } \mathrm{AN}-105,1.29 \mathrm{wt} \% \text { slurry, }\right. \\
0.06 \mathrm{gpm} / \mathrm{ft}^{2} \text { for } 0.1 \mu \mathrm{m} \text { disk). } \\
\text { - A concentration run was performed from } 1.29 \mathrm{wt} \% \text { to } 2.13 \mathrm{wt} \% \\
\text { (limitation was minimal amount of liquid in system). } \\
\text { - The filtrate clarity was }<<4 \text { ntu for both disks. }\end{array}$ \\
\hline $\begin{array}{l}\text { Herman et al. } \\
\text { (2011) } \\
\text { Testing of the Second } \\
\text { Generation SpinTek } \\
\text { Rotary Filter. }\end{array}$ & $\begin{array}{l}\text { This Waste Management Symposium proceeding describes the } 1000 \text { hour } \\
\text { test of the second generation } 25 \text {-disk unit at the SpinTek facility. The } \\
\text { slurry was prepared as a sludge batch } 6 \text { simulant with } 5,10 \text {, and } 15 \mathrm{wt} \% \\
\text { solids loading. The original Na molarity was } 5.6 \text { and was washed after } \\
\text { the } 1000 \text { hour test to less than } 1 \mathrm{M} \mathrm{Na} \text {. The main difference in the slurry } \\
\text { to other simulants is the low settling rate and the low mean particle size. } \\
\text { Summary of Results: } \\
\text { - All filtrate samples had }<2.5 \mathrm{ntu} \text { turbidity. Filtrate fluxes stabilized at } \\
2.5 \text { gpm ( } 5 \mathrm{wt} \% \text { ), } 2 \mathrm{gpm} \text { ( } 10 \mathrm{wt} \% \text { ) and } 1 \mathrm{gpm} \text { ( } 15 \mathrm{wt} \% \text { ). } \\
\text { - Several failures of auxiliary equipment (city power, chiller fire etc.) } \\
\text { caused interruptions of the endurance test. Actual accumulated } \\
\text { testing time was } 1500 \text { hours. } \\
\text { - The filter stack was inspected twice for equipment failures. The } \\
\text { silicon carbide journal bearing chipped and was replaced by a stellite } \\
\text { on nitronic } 60 \text { bearing. } \\
\text { Cleaning was performed with } 80 \text { liter of } 0.2 \mathrm{M} \text { nitric acid and resulted } \\
\text { in } ~ 90 \% \text { of the initial clean disk rate. } \\
\text { Vibrations were highly reduced compared to } 2009 \text { report (SRNL-STI- } \\
\text { 2009-00183). }\end{array}$ \\
\hline
\end{tabular}




\subsection{REFERENCES}

\begin{tabular}{|c|c|}
\hline Reference & Citation \\
\hline $\begin{array}{l}\text { Georgeton and } \\
\text { Poirier (1990) }\end{array}$ & $\begin{array}{l}\text { Georgeton G. K. and Poirier M. R.; Alternative Filtration Testing } \\
\text { Program: Pre-Evaluation of Test Results (U), WSRC-RP--90-1145, } \\
\text { Rev. O, Westinghouse Savannah River Company, Aiken, SC, September } \\
\text { 1990. }\end{array}$ \\
\hline $\begin{array}{l}\text { Stepan et al. } \\
\text { (1999) }\end{array}$ & $\begin{array}{l}\text { Stepan D. J., Stevens B. G., Hetland M. D.; EM Task 9-Centrifugal } \\
\text { Membrane Filtration. Final Report, 99-EERC-10-02, Energy \& } \\
\text { Environmental Research Center, University of North Dakota, Grand } \\
\text { Forks, ND, October } 1999 .\end{array}$ \\
\hline $\begin{array}{l}\text { Greene et al. } \\
\text { (1999) }\end{array}$ & $\begin{array}{l}\text { Greene W.A., Kirk P. A., Hayes R., Riley J.; Centrifugal Membrane } \\
\text { Filtration, Final Report, Contract No. DE-AC21-96MC3313, SpinTek } \\
\text { Membrane Systems, Inc., Huntington Beach, CA, } 1999 .\end{array}$ \\
\hline Poirier (2001) & $\begin{array}{l}\text { Poirier M. R.; Filtration Systems, Inc., Report for WSRC SpinTek Rotary } \\
\text { Microfilter Testing, WSRC-TR-2001-00214, Rev. 1, Westinghouse } \\
\text { Savannah River Company, Aiken, SC, 2001. }\end{array}$ \\
\hline $\begin{array}{l}\text { Herman et al. } \\
\text { (2003a) }\end{array}$ & $\begin{array}{l}\text { Herman D. T., Poirier M. R., Hobbs D. T., Fink S. D.; Testing of the } \\
\text { SpinTek Rotary Microfilter using Actual Waste, WSRC-TR-2003-00030, } \\
\text { Rev. O, Westinghouse Savannah River Company, Aiken, SC, February } \\
\text { 2003. }\end{array}$ \\
\hline $\begin{array}{l}\text { Poirier et al. } \\
\text { (2003) }\end{array}$ & $\begin{array}{l}\text { Poirier M. R., Herman D. T., Fink S. D., Haggard R., Deal T., Stork C., } \\
\text { Van Brunt V.; Pilot-Scale Testing of a SpinTek Rotary Microfilter with } \\
\text { SRS Simulated High Level Waste, WSRC-TR-2003-00071, Rev. 0, } \\
\text { Westinghouse Savannah River Company, Aiken, SC, February } 2003 .\end{array}$ \\
\hline $\begin{array}{l}\text { Herman et al. } \\
\text { (2003b) }\end{array}$ & $\begin{array}{l}\text { Herman D. T., Poirier M. R., Fink S. D.; Recommendations for } \\
\text { Additional Design Development of Components for the SpinTek Rotary } \\
\text { Microfilter prior to Radioactive Service, WSRC-RP-2003-00605, Rev. } \\
\text { 0, Westinghouse Savannah River Company, Aiken, SC, November } \\
2003 \text {. }\end{array}$ \\
\hline $\begin{array}{l}\text { Garn et al. } \\
(2003)\end{array}$ & $\begin{array}{l}\text { Garn T. G., Mann N. R., Herbst R. S., Todd T. A.; Experimental } \\
\text { Comparison of Mott, GKN, Pall and Graver Ultrafiltration Membranes } \\
\text { using Envelope A (AN-105) and Envelope D (AZ-101) Hanford } \\
\text { Simulants, INEEL/EXT-03-00887, Idaho National Engineering and } \\
\text { Environmental Laboratory, Idaho Falls, ID, July } 2003 \text {. }\end{array}$ \\
\hline $\begin{array}{l}\text { Mann et al. } \\
(2004)\end{array}$ & $\begin{array}{l}\text { Mann N. R., Herbst E. S., Garn T. G., Poirier M. R., Fink S. D.; } \\
\text { Alternative Ultrafiltration Membrane Testing for the SRS Baseline } \\
\text { Process, INEEL/EXT-04-12933, Idaho National Engineering and } \\
\text { Environmental Laboratory, Idaho Falls, ID, June } 2004 .\end{array}$ \\
\hline $\begin{array}{l}\text { Poirier et al. } \\
(2004 a)\end{array}$ & $\begin{array}{l}\text { Poirier M. R., Herman D. T., Fondeur F. F., Fink S. D., Haggard R., } \\
\text { Deal T., Stork C., Van Brunt V.; Pilot-Scale Testing of a Rotary } \\
\text { Microfilter with Irradiated Filter Disks and Simulated SRS Waste, } \\
\text { WSRC-TR-2004-00047, Rev. 0, Westinghouse Savannah River } \\
\text { Company, Aiken, SC, January 2004. }\end{array}$ \\
\hline Poirier et al. & Poirier M. R., Herman D. T., Fink S. D., Haggard R., Deal T., Stork C., \\
\hline
\end{tabular}




\begin{tabular}{|c|c|}
\hline$(2004 b)$ & $\begin{array}{l}\text { Van Brunt V.; Pilot-Scale Testing of a SpinTek Rotary Microfilter with } \\
\text { Welded Disks and Simulated Savannah River Site High Level Waste, } \\
\text { WSRC-TR-2004-00213, Rev. 0, Westinghouse Savannah River } \\
\text { Company, Aiken, SC, May 2004. }\end{array}$ \\
\hline $\begin{array}{l}\text { Poirier et al. } \\
(2004 \mathrm{c})\end{array}$ & $\begin{array}{l}\text { Poirier M. R., Herman D. T., Martin K. B., Siler J. L., Fink S. D.; } \\
\text { Impact of a Rotary Microfilter on the Savannah River Site High Level } \\
\text { Waste System, WSRC-RP-2004-00234, Rev. 0, Westinghouse Savannah } \\
\text { River Company, Aiken, SC, February 2004. }\end{array}$ \\
\hline $\begin{array}{l}\text { Poirier et al. } \\
(2004 d)\end{array}$ & $\begin{array}{l}\text { Poirier M. R., Herman D. T., Fondeur F. F., Fink S. D.; Development of } \\
\text { a Rotary Microfilter for Savannah River Site High Level Waste } \\
\text { Applications, (WSRC-MS-2004-00834), WM'05 Conference, February } \\
27 \text { - March 3, 2005, Tucson, AZ. }\end{array}$ \\
\hline $\begin{array}{l}\text { Poirier et al. } \\
(2005)\end{array}$ & $\begin{array}{l}\text { Poirier M. R., Herman D. T., Fink S. D.; Rotary Microfilter Media } \\
\text { Evaluation, WSRC-TR-2005-00205, Rev. 0, Savannah River National } \\
\text { Laboratory, Aiken, SC, April 2005. }\end{array}$ \\
\hline $\begin{array}{l}\text { Herman et al. } \\
(2006)\end{array}$ & $\begin{array}{l}\text { Herman D. T., Poirier M. R., Fink S. D.; Testing and Evaluation of the } \\
\text { Modified Design of the 25-Disk Rotary Microfilter, WSRC-STI-2006- } \\
\text { 00073, Rev. 0, Savannah River National Laboratory, Aiken, SC, August } \\
2006 \text {. }\end{array}$ \\
\hline $\begin{array}{l}\text { Poirier et al. } \\
(2008)\end{array}$ & $\begin{array}{l}\text { Poirier M. R., Herman D. T., Stefanko D. B., Fink S. D.; Testing of a } \\
\text { Rotary Microfilter to Support Hanford Applications, WSRC-STI-2008- } \\
\text { 00339, Rev. 0, Savannah River National Laboratory, Aiken, SC, June } \\
2008 \text {. }\end{array}$ \\
\hline $\begin{array}{l}\text { Herman et al. } \\
(2009)\end{array}$ & $\begin{array}{l}\text { Herman D. T., Stefanko D. B., Poirier M. R., Fink S. D.; Testing of a } \\
\text { Full-Scale Rotary Microfilter for the Enhanced Process for } \\
\text { Radionuclides Removal, SRNL-STI-2009-00183, Rev. 0, Savannah } \\
\text { River National Laboratory, Aiken, SC, January } 2009 .\end{array}$ \\
\hline $\begin{array}{l}\text { Huber et al. } \\
(2009)\end{array}$ & $\begin{array}{l}\text { Huber. H. J., Smith J. R., Warrant R. W.; Testing of the SpinTek Rotary } \\
\text { Microfilter using Simulated Hanford Waste Samples, RPP-RPT-40897, } \\
\text { Rev. 0, Washington River Protection Solutions LLC, Richland, WA, } \\
\text { April } 2009 .\end{array}$ \\
\hline $\begin{array}{l}\text { Huber et al. } \\
(2010)\end{array}$ & $\begin{array}{l}\text { Huber H. J., Edmonson D. W., Smith J. R.; Testing of the SpinTek } \\
\text { Rotary Microfilter using Actual Hanford Waste Samples, LAB- RPT-10- } \\
00002 \text {, Rev. 0, Washington River Protection Solutions LLC, Richland, } \\
\text { WA, April } 2010 .\end{array}$ \\
\hline $\begin{array}{l}\text { Herman et al. } \\
\text { (2011) }\end{array}$ & $\begin{array}{l}\text { Herman D. T., Poirier M., Fowley M., Keefer M., Huff T., Greene W., } \\
\text { Gilmour J.; Testing of the Second Generation SpinTek Rotary Filter - } \\
11357 \text { (SRNL-STI-2011-00056), WM2011 Conference, March 7-11, } \\
\text { 2011, Phoenix, AZ. }\end{array}$ \\
\hline
\end{tabular}

